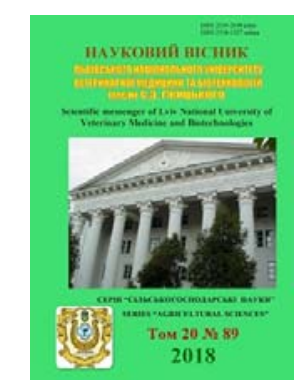

UDC 632.931:632.11

Науковий вісник Яьвівського націонадьного університету
ветеринарної медицини та біотехнологій імені С.3. Гжицького

\author{
Scientific Messenger of Lviv National University \\ of Veterinary Medicine and Biotechnologies
}

\title{
The optimization of modern measures of winter wheat protection from pests in the Forest-Steppe region of Ukraine
}

\author{
V. Sakhnenko, D. Sakhnenko \\ National University of Life and Environmental Sciences of Ukraine, Kiev, Ukraine
}

Article info

Received 31.08.2018 Received in revised form 27.09 .2018 Accepted 28.09.2018

National University of Life and Environmental Sciences of Ukraine, Heroiv Oborony 13 Kiev, 03041, Ukraine. Tel.: +38-067-214-01-14 E-mail:dolya@ukr.net
Sakhnenko, V., \& Sakhnenko, D. (2018). The optimization of modern measures of winter wheat protection from pests in the Forest-Steppe region of Ukraine. Scientific Messenger of Lviv National University of Veterinary Medicine and Biotechnologies, 20(89), 17-21. doi: 10.32718/nvlvet8903

The peculiarities of ecology of certain types of pests breeding in field crops are highlighted. The indicators of the influence of a complex of factors on development and mass reproduction of insects under modern agricultural systems are generalized. The species composition of insect phytophages in new crops is specified. More than 20 species of pests were identified that severely damaged this crop according to the results of the monitoring of the wheat entomocomplex. The analysis of influence of temperature, air and soil on the trophic links of phytophages and development and survival of their stages was conducted. A close connection between the level of productivity and the stages of organogenesis of plants with separate stages of development of the main species of phytophages was established. The analysis of efficiency of application of modern monitoring of a complex of pests at new systems of protection of winter wheat has been carried out. Cereal flies, aphids and other pests are found are found on wheat. The basic ecological and biological peculiarities of the formation of the entomocomplex of winter wheat are determined. The peculiarity of monitoring and control of harmful insect species on winter wheat crops in the forest-steppe of Ukraine is highlighted. The analysis of the modeling efficiency of the number of harmful and useful insect for resourcesaving systems of winter wheat protection is carried out. The peculiarities of biology and ecology of pests of stem and of the root system of winter wheat in the region of research are specified. The peculiarities of the formation of entomocomplexes in agrocenoses vary according to certain parameters, in particular the number of soil and interstitial phytophages, taking into account the radius of their daily displacement. It is relevant to determine the total demand of pests in feeding at the actual population of individuals at different stages of ontogenesis of grain crops for effective crop management. The application of resource saving models of the calculation of phytophage dynamics on cereal crops by hydrothermal coefficient at different periods of development of plants and phytophages in the production, which allows to determine the quantitative changes of a separate entomocomplex in grain crops in time and space. The development and introduction of integrated methods for the control of winter wheat pests according to modern agricultural systems in the forest-steppe of Ukraine, which determines the expected loss of grain in the crop fields becomes important.

Key words: phytophagous, agrocenosis, field crops, abiotic factors, prognosis, structure of the entomocomplex.

\section{Оптимізація сучасних заходів захисту пшениці озимої від шкідників в Лісостепу України}

\author{
В.В. Сахненко, Д.В. Сахненко
}

Національний університет біоресурсів і природокористування Украӥни, м. Київ, Україна

\footnotetext{
Висвітлено особливості екології окремих видів шкідників, щуо розмножуються в польових сівозмінах, і узагальнено показники впливу комплексу факторів на розвиток і масове розмноження комах при сучасних систем землеробства. Уточнено видовий склад комах-фітофагів у нових сівозмінах. За результатами моніторингу ентомокомплексу пшениці ідентифіковано понад 20 видів, які інтенсивно пошкоджували изю культуру. Проведено аналіз впливу температури, повітря і трунту на трофічні зв'язки фітофагів $i$ розвиток та виживання їх стадій. Встановлено тісний зв'язок рівня продуктивності та етапів органогенезу рослин із окремими стадіями розвитку основних видів фітофагів. Проведено аналіз ефективності застосування сучасного моніторингу комплексу
} 
икідників при нових системах захисту пшениці озимої. На сходах пшениці виявлені злакові мухи, попелиці та інші шкідники. Визначено основні еколого-біологічні особливості формування ентомокомплексу сходів пшениці озимої. Висвітлено особливість моніторингу та контролю шкідливих видів комах на посівах пшениці озимої в Лісостепу Украӥни. Проведено аналіз ефективності моделювання чисельності шкідлвих і корисних видів комах за ресурсоощадних систем захисту пшениці озимої. Уточнено особливості біологї̈ та екології шкідників стебел і кореневої системи пшеничі озимої в регіоні досліджень. Особливості формування ентомокомплексів в агроценозах варіюють за певними показниками, зокрема чисельності трунтових та внутрішньостеблових фітофагів $з$ урахуванням радіуса їх добового переміщення. Для ефективного ведення рослинництва актуальним є визначення сумарної потреби шкідників у живленні за фактичної сукупності особин виду на різних етапах онтогенезу зернових культур. Застосування у виробництві ресурсоощадних моделей розрахунку динаміки фітофагів на посівах зернових культур за гідротермічним коефіцієнтом у різні періоди розвитку рослин і фітофагів, шуо дозволяє визначити кількісні зміни окремого ентомокомплексу на посівах зернових культур у часі і просторі. За сучасних систем землеробства в Лісостепу України важливого значення набуває розробка і впровадження у виробниџтво комплексних методів щзодо контролю шкідників пшениці озимої, щзо визначає очікувані втрати зерна на полях сівозміни.

Ключові слова: фітофаги, агроченоз, польові культури, абіотичні фактори, прогноз, структура ентомокомплексу.

\section{Вступ}

В 2000-2017 рр. при спостереженнях ентомокомплексів зернових культур за різних типів сівозмін і тривалості ротації уточнені особливості біології та екології комплексу видів шкідників. Зокрема, залежно від систем удобрення, захисту посівів і обробітку грунту, визначена здатність польових культур відновлювати розвиток і ріст при пошкодженні фітофагами на різному фоні родючості та забезпеченості рослин поживними речовинами. Встановлено, що у нових сівозмінах протягом однієї-двох ротацій із зміщенням до порівняно ранніх строків посіву пшениці озимої чисельність спеціалізованих видів шкідників підвищується на 20-23\% порівняно 3 контролем.

Актуальність теми: сутність проблеми розвитку сільського господарства полягає у захисті сходів пшениці озимої від комплексу шкідників. Особливого значення набувають високоефективні технології, що спрямовані на вдосконалення прийомів щодо контролю комплексу шкідників на посівах пшениці озимої за основними етапами органогенезу культури, зокрема, шкідливих видів внутрішньостеблових фітофагів та інших організмів, що пошкоджують пшеницю озиму.

Чимало наукових робіт присвячені особливостям захисту сільськогосподарських культур за різних погодно-кліматичних умов (Adamenko, 2006; Oliveira et al., 2014; Lorenzo et al., 2016; Milosavljevic and Esser, 2016). Так, для виявлення та подальшого захисту зернових культур від шкідників застосовують різні технології та методи контролю фітофагів у сучасному землеробстві (Andriichenko et al., 2004; Bomba, 2007; Jevtic et al., 2017; Bayram and Tonga, 2018). Дослідження проводили за загальноприйнятими методиками, із застосуванням розрахунково- порівняльного та математично-статистичного методів аналізу експериментальних данних (Chaika et al., 2005; Havryliuk, 2009; Kulieshov et al., 2011).

Мета і завдання дослідження. Оцінка ефективності застосування інноваційних систем контролю комплексу фітофагів на пшениці озимій у сучасних погодно-кліматичних умовах в Лісостепу України.

\section{Матеріал та методи досліджень}

Фітосанітарний та агроекологічний аналіз результатів досліджень зарубіжних і вітчизняних фахівців здійснено на основі реальних і прогнозованих показ- ників щодо використання інноваційних технологій вирощування пшениці озимої в Лісостепу України. Інформаційною базою дослідження є результати спостережень служби Департаменту фітосанітарної безпеки контролю в сфері насінництва та розсадництва і наукові праці, присвячені проблемам нових технологій обробітку грунту, особливостям формування ентомокомплексу зернових культур за різних систем обробітку грунту та впливу рідких мінеральних добрив на динаміку заселення пшениці озимої шкідниками, а також періодичні видання, статистичні дані, електронні ресурси і результати власних досліджень за 2000-2017 pp.

Експерименти виконували в Агрономічній дослідній станції НУБІП, Київська область, Васильківський район, а також в навчально-науково-виробничому центрі “В. Обухівське” Миргородський район, Полтавська область та інших базових господарствах Лісостепу України. Розроблені математичні моделі поширення шкідників пшениці озимої з уточненими закономірностями процесів у розвитку окремих грунтових i внутрішньостеблових видів за виявленою їхньою чутливістю до антропогенного фактору.

\section{Результати та їх обговорення}

Встановлено, що від початку проростання насіння пшениці озимої і протягом усієї вегетації, рослини пошкоджуються різними шкідливими видами комах. В осінній період посіви заселяють і пошкоджують: хлібний турун, підгризаючі совки, злакові мухи, злакові цикадки, попелиці. 3 початком відновлення весняної вегетації ці шкідники продовжують живлення на посівах пшениці озимої.

Місцями пошкоджують рослини хлібна смугаста блішка, червоногруда п'явиця і комплекс видів клопів, зокрема клопом шкідливою черепашкою. В фазу колосіння і наливу зерна, генеративні органи заселяють злакові попелиці і пшеничний трипс, личинки клопа-черепашки. Перед збиранням урожаю зерна частина його пошкоджується хлібними жуками, жуками хлібного туруна та іншими.

Так, хлібний турун (Zabrus tenebrioides G.) - найнебезпечніший фітофаг озимої пшениці, з вираженою пристосованістю до засушливого і жаркого клімату. Цикл розвитку від яйця до дорослої комахи проходить в грунті за один рік, але живляться жуки і личинки 
наземними частинами рослин, зазвичай після стерньових попередників.

Основну шкоду посівам наносять личинки, які в своєму розвитку проходять три віки. Для запобігання зростання чисельності та підвищення шкідливості туруна першочерговим $\epsilon$ дотримання науковообгрунтованого чергування культур в сівозміні.

В 2000-2017 pр. відчутної шкоди посівам завдавала чорна пшенична (Phorbia securis Tiens), місцями гессенська (Mayetiola destructor S.) та шведська
(Oscinella pusilla Mg). Шкідливість їх личинок на пшениці озимій проявлялась восени при пошкодженні посівів раннього строку висіву і після стерньових попередників.

В роки спостережень відмічено інтенсивне розмноження пшеничної мухи, що спостерігалося в 2012-2015 роках, однак в 2016-2017 роках цей фітофаг практично не заселяв пшеницю озиму, що пов'язано з погодними та іншими факторами (рис. 1).

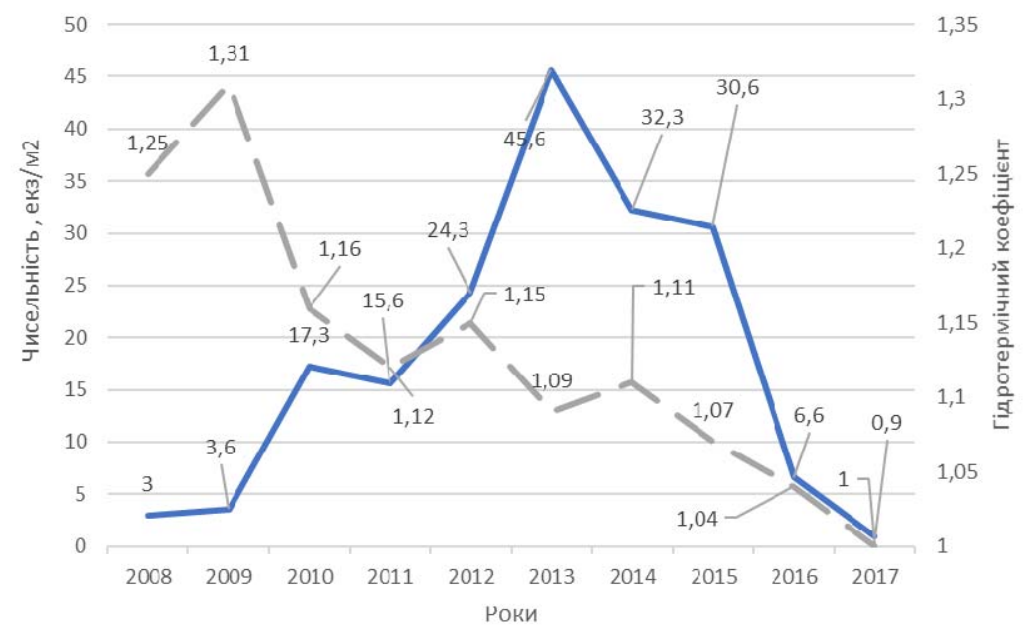

Рис. 1. Модель динаміки розмноження пшеничної мухи на посівах пшениці озимої (2000-2017рp.)

Посівам пшениці озимої щорічно шкоди завдавали сисні шкідники (хлібні клопи, трипси, злакові попелиці). Шкідлива черепашка (Eugaster integriceps Put.) пошкоджувала пшеницю озиму, починаючи 3 моменту появи його на посівах і до вильоту на зимівлю. Спочатку при заселенні клоп пошкоджував листя рослин, пізніше стебло і колос. При уколі в стебло на початку виходу в трубку у рослини жовтів і засихав верхній лист.

При колосінні такий колос набував білоколосісті, що призводило до зниження урожаю та погіршення його якості. Основну шкоду наносять личинки, шкодочинність яких залежить від їхнього віку. Зерно, що пошкоджено личинками молодших віків (другоготретього), деформувалося і його маса зменшувалась. Личинки старших віків (четвертого-п'ятого), а також клопи нового покоління менше впливали на кількість урожаю, але сприяли погіршенню хлібопекарських якостей.

В роки досліджень серед злакових попелиць в агроценозі озимої пшениці домінуючими видами виявились звичайна (Schizaphis graminum R.) і велика (Sitobion avenae F.) та інші. Попелиці висмоктували 3 рослин соки, порушували у них формування вегетативних і генеративних органів.

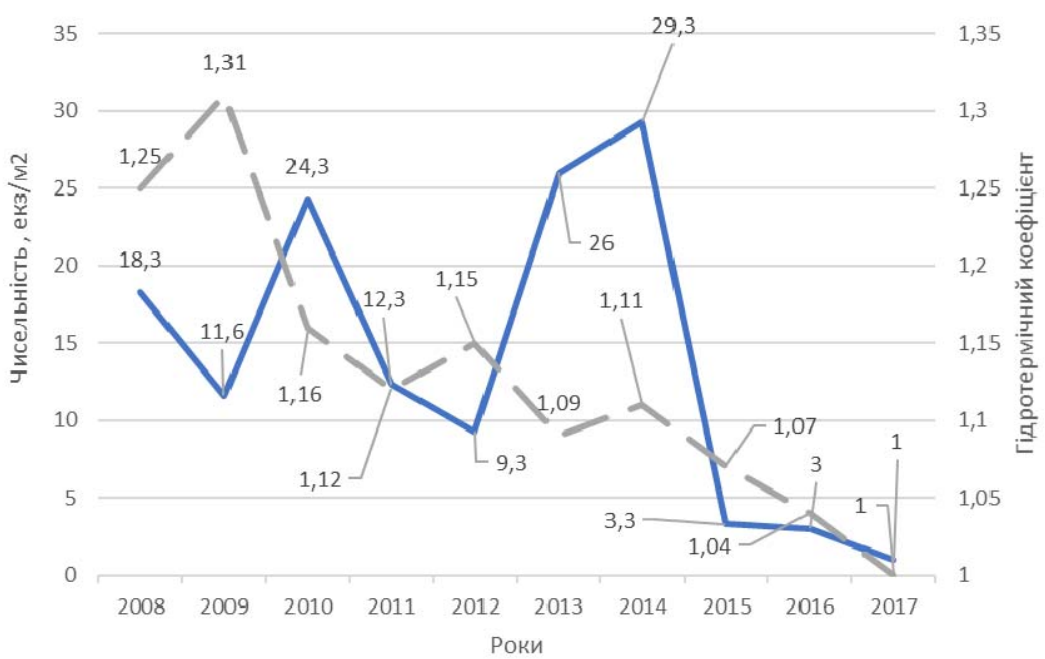

Рис. 2. Модель динаміки розмноження злакових попелиць на посівах пшениці озимої (2000-2017рp.) 
В роки досліджень спалахи розмноження злакових попелиць спостерігали у 2013 році і 2016-2017 роках при максимальній чисельності до 29,3 екз/м² на рослину. Це пов'язано з оптимальними погодними умовами та показниками гідротермічного коефіцієнту 1,25 (рис. 2).

В періоди виходу пшениці озимої в трубку шкодили імаго пшеничного трипса (Haplothrips tritici Kurd.) і розвивалися за піхвою верхнього листка, а личинки живилися спочатку колосковими лусочками, а потім зерном, що призводить до білоколосості i щуплозерності із зниженням урожаю зерна сучасних та перспективних сортів пшениці озимої.

У зв'язку із вищевказаним нагальним є проведення організаційно-господарських, агротехнічних, хімічних, біологічних та інших засобів захисту рослин за показниками сезонного та багаторічного циклів розмноження шкідників пшениці озимої. Це дозволяє запобігти масовому розвитку шкідників на посівах, знизити їхню шкідливість і не допустити зниження якості врожаю, попередити накопичення мікрозалишків препаратів у агроценозах.

Нагальними є кількісні та якісні організаційногосподарські заходи, що передбачають виконання робіт, пов'язаних з обстеженням посівів із інформацією про розповсюдження, чисельність, фенологію комплексу шкідників, загальний стан посівів, густоту стояння стеблестою, фазу розвитку рослин, в тому числі планування і проведення найбільш ефективних і економічно обгрунтованих захисних заходів щодо контролю фітофагів за фазами органогенезу пшениці озимої.

Першочерговими є агротехнічні заходи із проведення ресурсоощадної своєчасної і якісної підготовки грунту, оптимальних строків сівби, використання рідких форм добрив; виконання технологічних заходів догляду за посівами, включаючи хімічні та біологічні обробки при масових появах на них шкідників; збирання без втрат і в стислі строки урожаю. Особливе значення в фітосанітарному плані має підготовка поля під посів пшениці озимої.
При цьому застосування рідких мінеральних добрив прямого впливу на більшість видів шкідників не виявляють, але в збалансованій кількості вони сприяють одержанню порівняно дружніх сходів, швидкому росту, підвищують енергію і темпи кущіння, в результаті чого підвищується опірність рослин до пошкоджень комахами із колюче-сисним ротовим апаратом, злаковими мухами, листоїдами та іншими. Однак при надлишковому азотному живленні змінюється фізіологічний стан рослин, внаслідок чого створюються сприятливі умови для розвитку і розмноження злакових попелиць, клопів, цикадок та інших.

Оособливим регулюючим агротехнічним прийомом обмеження чисельності шкідників на посівах пшениці озимої є строки сівби культури. При цьому істотну роль у захисті рослин від фітофагів відіграють порівняно пізні строки сівби, при яких не активно заселялися грунтовими шкідниками, злаковими мухами, сисними фітофагами, злаковими попелицями, цикадками.

Посів необхідно проводити високоякісним насінням районованих сортів озимої пшениці. Важливе значення має впровадження сортів, стійких до пошкоджень шкідниками, із обов'язковим протруєнням посівного матеріалу інсектицидами.

Це дозволяє поєднувати обробку насіння і проти комплексу хвороб, усунути на початку вегетації культури шкідливість не тільки хлібного туруна, але i підгризаючих совок, дротяників, а також проти злакових мух, злакових попелиць, цикадок та інших фітофагів.

Від фітосанітарного стану посівів восени дуже залежить їх весняно-літній стан i формування майбутнього урожаю. Тому з появою сходів озимої пшениці і до кінця осінньої вегетації необхідно встановити постійний контроль за фітосанітарним станом посівів. При виявленні на посівах хлібного туруна (12 - у фазі сходів - 3-й листок, 2-3 личинки/м² - на початку кущіння), підгризаючих совок (2-3 гусені/ $\left.\mathbf{M}^{2}\right)$ проводиться обприскування (крайове, вибіркове в осередках розмноження шкідників або суцільне) дозволеними до застосування інсектицидами.

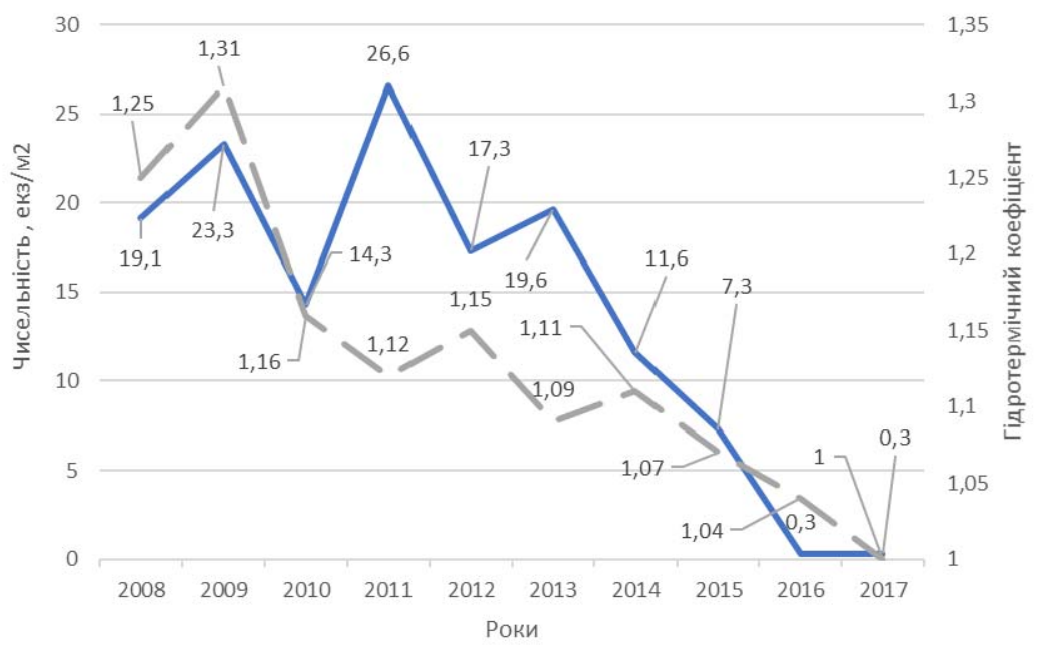

Рис. 3. Модель динаміки розмноження озимої мухи на посівах пшениці озимої (2000-2017рp.) 
При цьому використання бакових сумішей інсектицидів фосфорорганічної або піретроїдної груп у половинних від рекомендованих нормах з додаванням 5-7 л/га КАС сечовини є обов'язковим і ефективним. Враховуючи вікову чутливість личинок хлібного туруна до інсектицидів та сутінкове і нічне їх живлення, обробку рослин доцільно проводити у надвечірню пору.

За умови теплої тривалої осені посіви озимої пшениці масово заселяються сисними шкідниками (злаковими попелицями та цикадками), що в нашій зоні небезпечні насамперед як переносники вірусних захворювань. При кількості попелиць 5-10 особин/рослину (при 50\% заселенні рослин), цикадок 70-150 особин/м² посіви обробляють тими ж препаратами, що і проти злакових мух.

Так, в 2008-2013 роках сходи озимої пшениці порівняно інтенсивно пошкоджували личинки озимої мухи, які заселяли основні та другорядні стебла, а кількість пошкоджених місцями рослин складала 26,6\%. В 2015-2017 роках цей фітофаг практично не заселяв пшеницю озиму (рис. 3).

У фазу виходу рослин озимої пшениці в трубку на посівах зростає чисельність та шкідливість сисних шкідників і насамперед клопа шкідливої черепашки. Для захисту агрофітоценозу від клопів, що перезимували (дві і більше особин на квадратному метрі) достатньо обмежитись обробкою крайових смуг шириною 100-150 м одним із зареєстрованих інсектицидів.

\section{Висновки}

Таким чином, інтенсивність розвитку, розмноження і поширення фітофагів, їхн шкодочинність значною мірою залежить від комплексу факторів, серед яких основними $є$ сучасна структура сівозмін, добрива, а також абіотичні чинники та система заходів захисту зернових культур від шкідливих видів комах на основних стадіях їхнього розвитку.

В 2000-2017 рр. під дією комплексу чинників довкілля фітосанітарний стан агроценозів України достовірно залежав від типу сівозміни та норм внесень рідких форм мінеральних добрив. Екологічні чинники впливали на поширення та шкодочинність спеціалізованих комах-фітофагів в сучасних агроценозах регіону досліджень як на посівах пшениці озимої, так і інших зернових культурах в Лісостепу України.

Перспективи подальших досліджень. При плануванні і освоєнні польових сівозмін доцільно звернути увагу на біологічні заходи захисту для зменшення чисельності шкідників. За принципом ефективної локалізації варто скоротити виробництво товарного зерна пшениці на грунтах із порівняно низькими показниками гумусу на користь фуражних культур, що в результаті збільшить кількість хижих жужелиць та інших видів корисних комах в агроценозах.

Сучасні системи захисту зернових культур передбачають застосування комплексного захисту, починаючи з оптимізації сівозміни, підготовки насіння до сівби та початкових фаз розвитку рослин, зокрема, підвищення стійкості рослин проти комплексу фітофагів та інших шкідливих чинників шляхом протруєння насіння інсектицидами $з$ одночасною обробкою його мікро- та макроелементами.

\section{References}

Adamenko, T.I. (2006). Zminy ahroklimatychnykh umov kholodnoho periodu v Ukraini pry hlobalnomu poteplinni klimatu. Ahronom, 34, 12-13 (in Ukrainian).

Lyfenko, S.P., Lytvynenko, M.A., \& Chaika, V.H. (2009). Yaki stroky sivby optymalni. Nasinnytstvo, 11, 3-5 (in Ukrainian).

Havryliuk, M. (2009). Osoblyvosti zakhystu silskohospodarskykh kultur vid shkidnykiv i khvorob. Ahrarnyi tyzhden Ukrainy, 5, 12 (in Ukrainian).

Andriichenko, L.V., Khomiak, P.V., Rybka, V.S., \& Kompaniiets, V.O. (2010). Ahroekolohichni ta ekonomichni aspekty vyroshchuvannia ozymoi pshenytsi v umovakh Pivdennoho Stepu Ukrainy. Ekolohiia. Naukovi pratsi, 132(119), 41-44. http://ecology.chdu.edu.ua/article/view/64833 (in Ukrainian).

Kulieshov, A.V., Bilyk, M.O., \& Dovhan, S.V. (2011). Fitosanitarnyi monitorynh i prohnoz: navch. posibnyk. Kharkiv. Espada (in Ukrainian).

Bomba, M.Ya. (2007). Suchasni tendentsii rozvytku svitovoho zemlerobstva: Visnyk NAN Ukrainy, 12, 3440. http://nbuv.gov.ua/UJRN/vnanu_2007_12_7 (in Ukrainian).

Chaika, V.M., Siadrysta, O.B., \& Kozak, H.P. (2005). Bahatorichna dynamika chyselnosti shkidnykiv ozymyny v Lisostepu. Karantyn i zakhyst roslyn, 6, 11-13 (in Ukrainian).

Oliveira, C., Auad, A., Mendes, S., \& Frizzas, M. (2014). Crop losses and the economic impact of insect pests on Brazilian agriculture. Crop Protection, 56, 50-54. doi: 10.1016/j.cropro.2013.10.022.

Bayram, A., \& Tonga, A. (2018). Cis-Jasmone treatments affect pests and beneficial insects of wheat (Triticum aestivum L.): the influence of doses and plant growth stages. Crop Protection, 105, 70-79. doi: 10.1016/j.cropro.2017.11.011.

Jevtic, R., Zupunski, V., Lalosevic, M., \& Zupunski, L. (2017). Predicting potential winter wheat yield losses caused by multiple disease systems and climatic conditions. Crop Protection, 99, 17-25. doi: 10.1016/j.cropro.2017.05.005.

Lorenzo, F., Vasileios, P., Francesca, C., Hilfred, H., Leskovsek, R., Razinger, J., Sartori, E., Holb, I., Verschwele, A., Isadora, B., \& Sattin, M. (2016) Risk assessment of soil-pest damage to grain maize in Europe within the framework of Integrated Pest Management. Crop Protection, 97, 52-59. doi: 10.1016/j.cropro.2016.11.029.

Milosavljevic, I., \& Esser, A.D. (2016). Effects of environmental and agronomic factors on soil-dwelling pest communities in cereal crops. Agriculture Ecosystems \& environment, 225, 192-198. doi: 10.1016/j.agee.2016.04.006. 